\title{
ANALYSIS OF THE TECHNICAL-TACTICAL CHARACTERISTICS OF THE IVECO LORRY EUROCARGO MODEL WITH REGARD TO MEETING SOME OF THE OPERATIONAL REQUIREMENTS FOR SPECIFIC MISSIONS
}

\author{
Ioan VIRCA \\ "Nicolae Bălcescu" Land Forces Academy, Sibiu, Romania \\ virca_ioan@yahoo.com
}

\begin{abstract}
Currently, the force and logistic structures are going through a process of replacing the old equipment, physically and morally worn, and the new ones that have been bought or which are going to be selected must meet a series of operational requirements imposed by the beneficiary and through which the missions in which they will participate can be carried out. Such an analysis of the main technical and tactical features of the equipment is beneficial to users because the results of the calculations and assessments will enable command and decision makers to provide the most rational solutions from a technical and economical point of view in order to solve and perform the logistical tasks. On the other hand, thorough military knowledge of the technical and tactical possibilities of the equipment will allow the integrated planning of strategic and operative level actions, for which this equipment will be successful. In this article, the author analyzes the technical-tactical characteristics of a modern IVECO lorry, EUROCARGO 15 To $4 \times 4$ model, using as a research method the comparison of specific characteristics and sizes with the values recommended in the specialized literature and those expressed in the requirements of the beneficiaries.
\end{abstract}

\section{Keywords: lorry, characteristics, Iveco, logistics, missions}

\section{Introduction}

The process of equipping the structures of the Romanian armed forces with modern equipment is an ongoing process, an important direction being the endowment of the modern, performing and cost-efficient transport formations reported to the budgets allocated for this purpose.

From the offered choices, the solution is established so that it satisfies the operational requirements of the beneficiaries, namely those that meet the destination criteria, strategic, operative and tactical mobility, safety of the movement and protection of the environment.

As a result, the destination of trucks for the military system refers to the execution of those missions and tasks for the purpose of logistically assuring the fighting forces on all three above-mentioned levels and of solving the related problems deriving from the main purpose: recovery, evacuation, maintenance.

The specific tasks to be performed by this category of vehicles are the following:

- transport of material goods for the logistics of current activities and military actions, individually or in convoys on or off the road communications;

- transport of soldiers by complying with the regulations regarding the transport of persons by means of vehicles;

- with legal additional technical equipment, they can be used as vehicles designed to 
teach driving in order to obtain the driving license category " $\mathrm{C}$ ";

- evacuation and recovery of other vehicles stuck on the battlefield or in other situations;

- when needed, in the absence of specialized technical means, they can also participate in special actions, for the transport of wounded persons, personal escorts, mobile maintenance, etc.

Consequently, in order to accomplish these missions, the vehicles must meet the aforementioned operational requirements. For a purchased vehicle type, some of the requirements will be discussed in the following paragraphs.

2. The analysis of the technical tactical characteristics of the IVECO lorry EUROCARGO 15 To 4x4 model

This model of lorry (Figure no.1) has recently come in the provision of transport assurance formations, being considered by the specialists a model that corresponds to the current technical tactical requirements regarding the conduct of the training, the accomplishing of logistical missions and tasks, the cost of acquisition and the maintenance on life cycle of the product.

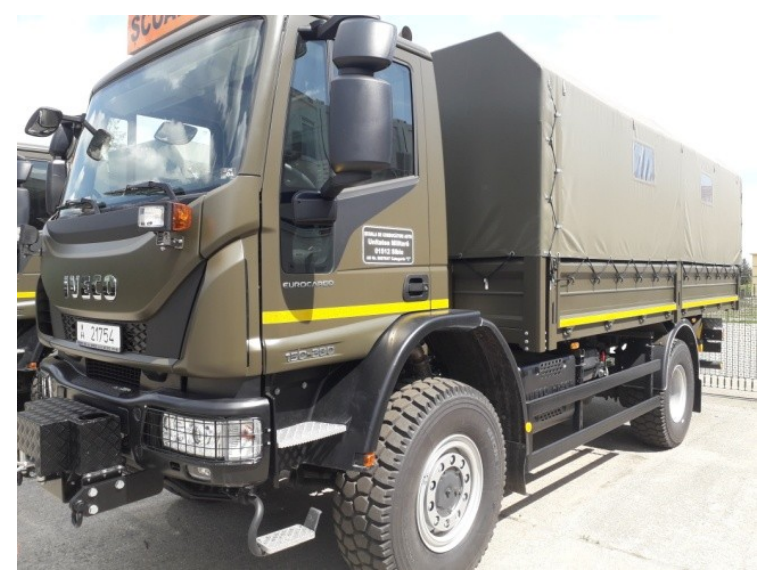

Fig. 1. Overview of the IVECO lorry EUROCARGO 15 To $4 \times 4$ model

This truck is a medium-size type, with its own mass of $\mathrm{mp}=8,350 \mathrm{~kg}$, and the weight of the load is $6,650 \mathrm{~kg}$. It has an increased capacity for crossing to off road, and for the evacuation of other vehicles it is equipped with a winch at the front. The analysis of the main technical-tactical characteristics is made in table no. 1 .

Table no. 1 The main characteristics of IVECO lorry EUROCARGO 15 To $4 \times 4$ model

\begin{tabular}{|l|l|l|}
\hline \multicolumn{1}{|c|}{ Characteristic/Size } & \multicolumn{1}{|c|}{ Real value } & \multicolumn{1}{c|}{ Recommended value/Comments } \\
\hline $\begin{array}{l}\text { Wength } \\
\text { Height }\end{array}$ & $\begin{array}{l}7.47 \mathrm{~m} \\
2.49 \mathrm{~m} \\
3.45 \mathrm{~m}\end{array}$ & $\begin{array}{l}\text { With these dimensions, the truck can be } \\
\text { embarked on strategic airplanes, by rail and } \\
\text { by sea, and on the road it is considered to } \\
\text { be ordinary vehicle without oversized } \\
\text { dimensions that would require additional } \\
\text { accompaniment. }\end{array}$ \\
\hline Wheelbase & $4.15 \mathrm{~m}$ & $\begin{array}{l}\text { The } 4.15 \mathrm{~m} \text { is an acceptable value, being a } \\
\text { compromise between the need to easily } \\
\text { enclose the bends and avoid the vehicle's } \\
\text { pitching movements, especially when } \\
\text { loaded, and the center of gravity rises. }\end{array}$ \\
\hline Gauge & $2.08 \mathrm{~m}$ & $\begin{array}{l}\text { The value of 2.08 m satisfies the need to } \\
\text { maintain lateral stability in lateral corners } / \\
\text { slopes and to make a re-ribbon gauge (Re- } \\
\text { Ri) convenient for turning. }\end{array}$ \\
\hline
\end{tabular}




\begin{tabular}{|c|c|c|}
\hline The angle of attack & $27^{\circ}$ & $\begin{array}{l}\text { It is relatively small due to the winch in } \\
\text { front of the vehicle and can cause } \\
\text { obstructions when ramps climb or downhill } \\
\text { slopes, but current military actions are } \\
\text { usually carried out near land-based } \\
\text { communications. }\end{array}$ \\
\hline $\begin{array}{l}\text { Ground clearance } \\
\text { (minimum ground } \\
\text { clearance) }\end{array}$ & $0.390 \mathrm{~m}$ & $\begin{array}{l}\text { Recommended value: } 0.3-0.5 \mathrm{~m} \\
\text { There is a sufficient distance to cross heavy } \\
\text { obstacle, marshy, turbulent or even } \\
\text { mountainous land. It also contributes to the } \\
\text { achievement of large angles of attack and } \\
\text { clearance, which are beneficial for crossing } \\
\text { major obstacles or ramps. }\end{array}$ \\
\hline Autonomy of functioning & $800 \mathrm{~km}$ & $\begin{array}{l}\text { Recommended value: } 800-1000 \mathrm{~km} \\
\text { The engine of the vehicle, with a cubic } \\
\text { capacity of } 6728 \mathrm{cc} \text {, consumes an average } \\
\text { of } 251 / 100 \mathrm{~km} \text { and the capacity of the fuel } \\
\text { tank is } 200 \mathrm{l} \text {. }\end{array}$ \\
\hline Specific power & $\begin{array}{c}P_{s p}=\frac{P_{\mathrm{m}}}{\mathrm{m}}=\frac{280}{15} \\
= \\
18,66 \mathrm{hp} / \mathrm{t}\end{array}$ & $\begin{array}{l}\text { Recommended value: } 12-24 \mathrm{CP} / \mathrm{t} \\
\text { The calculation was made at the total mass } \\
\text { of } \mathrm{m}=15 \mathrm{t} \text {. The powerful } 280 \mathrm{hp} \text { engine } \\
\text { will achieve good traction and mobility } \\
\text { qualities, with the overall engine power for } \\
\text { this vehicle category being between } 200- \\
300 \mathrm{hp} \text {. }\end{array}$ \\
\hline Maximum power & $\begin{array}{l}\mathrm{P}_{\max }=280 \mathrm{hp} \\
(207 \mathrm{~kW}) \\
\text { At the maximum } \\
\text { speed of } \mathrm{n}=2500 \\
\text { rot } / \mathrm{min}\end{array}$ & 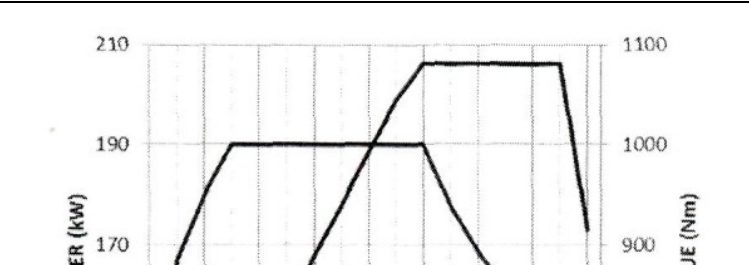 \\
\hline $\begin{array}{l}\text { Torque or maximum } \\
\text { engine torque }\end{array}$ & $\begin{array}{l}M_{\max }=100 \mathrm{daNm} \\
\text { on the speed line } \\
1250-1970 \mathrm{rpm}\end{array}$ & $\begin{array}{l}800110014001600180019702200240022600 \\
\text { ENGINE SPFED (RPM) } \\
\text { The maximum torque lies on a range of } \\
\text { over } 700 \mathrm{rpm} \text { due to the electronic fuel } \\
\text { injection equipment. }\end{array}$ \\
\hline $\begin{array}{l}\text { The maximum moment } \\
\text { on the wheels of the } \\
\text { truck }\end{array}$ & $\begin{array}{l}\mathrm{M}_{\mathrm{r}}=\mathrm{M}_{\max } \times \mathrm{i}_{\mathrm{T}} \times \eta_{\mathrm{t}}= \\
100 \times 46.91 \times 0,9= \\
4422 \mathrm{daNm} \\
\text { (in the first level } \\
\text { of the gearbox) }\end{array}$ & $\begin{array}{l}\text { The } 4422 \text { daNm of the wheel torque is very } \\
\text { high due to the significant reduction of the } \\
\text { speed in the transmission components, } \\
\text { which will result in a high wheel drive } \\
\text { force, thus a good vehicle progress in the } \\
\text { field. }\end{array}$ \\
\hline
\end{tabular}




\begin{tabular}{|l|l|l|}
\hline $\begin{array}{l}\text { The dynamic range of the } \\
\text { wheels of the truck }\end{array}$ & $\mathrm{r}_{\mathrm{r}}=0.6 \mathrm{~m}$ & $\begin{array}{l}\text { The truck is equipped with classical tires } \\
\text { for this category of vehicles, respectively } \\
\text { 14.00R20 Tubless. A major inconvenience } \\
\text { is the lack of tire inflating equipment, } \\
\text { which affects the ability to move in heavy } \\
\text { terrain. }\end{array}$ \\
\hline $\begin{array}{l}\text { The traction force on the } \\
\text { wheels of the vehicle }\end{array}$ & $\begin{array}{l}F r=\frac{\mathrm{M}_{\mathrm{r}}}{\mathrm{r}_{\mathrm{r}}}=\frac{4422}{0.6} \\
=7370 \text { daN }\end{array}$ & $\begin{array}{l}\text { This traction force on the wheels of the } \\
\text { vehicle will overcome the inertia force of } \\
\text { the vehicle and other strength forces } \\
\text { (rolling, starting, downhill, air, hook) }\end{array}$ \\
\hline $\begin{array}{l}\text { Winch with electric drive } \\
7.8 \mathrm{CP} \text { (motor electric de }\end{array}$ & $\begin{array}{l}\text { Load capacity } \\
5897 \mathrm{~kg} \\
\text { Towing cable } \\
\text { length } 30 \mathrm{~m} \\
\text { Control with radio } \\
\text { control }\end{array}$ & $\begin{array}{l}18 \text { places } \\
\text { Seats, seat belts } \\
\text { and head restraints } \\
\text { comply } \\
\text { UNECE } \\
\text { Regulations } \\
16,17\end{array}$ \\
\hline $\begin{array}{l}\text { Removable seat system } \\
\text { for military transport }\end{array}$
\end{tabular}

\section{Conclusions}

In paragraph 2, only a part of the technical and tactical characteristics of IVECO EUROCARGO lorry 15 To $4 \times 4$ model were analyzed, for reasons of space. A thorough approach could lead to an ample study of operating and maintenance staff. It is certain that the items analyzed are highperformance and determine the availability of the whole system - the vehicle.

Specific conclusions from the analysis:

-the dimensions of the vehicle and the performance of the motor-transmissionpropulsion assembly make it possible to achieve high pass-through capacity in cross-country terrain;

- the additional equipment meets the military requirements for missions;

- high reliability of the components.

Acknowledgements

This article is part of the author's study on the knowledge and use of IVECO lorries in the military environment.

\section{References}

[1] Neculăiasa Vasile, Mişcarea autovehiculelor, Polirom Publishing House, 1996, pp. 23-41, 99-114, 209-219.

[2] Virca Ioan, Arma Auto - 100 de ani de existenţă - Tradiţie, Continuitate şi Perspective. Land Forces Academy Publishing House, 2017, 400 pages, ISBN 978-973-153-267-7.

[3] Specificatii tehnice şi caracteristici ale autocamioanelor IVECO model EUROCARGO 15 To $4 \times 4$, from the technical notes of the producer.

[4] https://www.iveco.com/romania/produse/pages/noul-eurocargo.aspx. 